\title{
The Prevalence of Dental Midline Deviation in a Group of Orthodontic Patients
}

\begin{abstract}
DANIELA ANISTOROAEI, GEORGETA ZEGAN*, IULIA CATALINA SAVEANU*, ALINA SODOR, LOREDANA GOLOVCENCU
Grigore T. Popa University of Medicine and Pharmacy Iasi, Faculty of Dentistry, Department of Surgical, 16 Universitatii Str., 700115, lasi, Romania

The study aimed to determine the prevalence of dental midline deviation in an orthodontic group of patients.The study was performed on 384 orthodontic patients ( 164 boys and 220 girls), between 6-23 years old. The data collected from orthodontic records were analysed according to the gender, age stages, environments areas, type of dentition and Angle Classes of malocclusions. All analyses were carried out using the SPSS. In the studied group the prevalence of dental midline deviation was $20.70 \%$. The prevalence of dental midline deviation was increased in girls (12.24\%), in patients over 12 years old (8.35\%), from urban areas (14.32\%), with mixed dentition (11.45\%) and with Class I (11.20\%) and II division 1 (6.25\%) malocclusions. We founded statistically significant high correlations between dental midline deviation and age stages $(p=0.028)$, type of dentition $(p=0.001)$ and Angle classes of malocclusions $(p=0.006)$. The dental midline deviation, commonly encountered in orthodontic practice, must be accurately diagnosed from the beginning of the treatment because the symmetry of the midlines is an essential criterion in achieving the aesthetic and functional objectives of the orthodontic treatment.
\end{abstract}

Key words: prevalence, dental midline deviation, malocclusion, mixed dentition, permanent dentition

The need to improve facial aesthetics is one of the main reasons why patients are addressing the orthodontist, facial symmetry having a determining importance in facial aesthetics. Face symmetry and midline coordination are essential criteria for achieving harmony and facial balance. Aesthetic criteria require that certain facial landmarks of the face (the bisector of the pupil, nasion, tip of the nose, tip of the philtrum and chin) be placed in the same axis, forming facial midline $[1,2]$. Also for face symmetry the facial midline must be coincident with the maxillary and mandibular dental midline (dental midline is an imaginary line separating the two central incisors) in maxilla or mandible $[3,4]$.

For each patient, there is a subtle degree of asymmetry, but the clinically noticeable deviation of the median structures (nose, upper lip philtrum, chin, or dental midline) is not considered normal. In orthodontic patients, the maxillary, mandibular dental midlines and the facial soft tissue midline often are not coincident with each other [5].

Often dental midline deviation, as well as drifting and tipping of teeth, asymmetries of dental arch are the consequences of compensatory changes produced intraorally by skeletal or dento-alveolar asymmetries.

Dental midline position relative to the facial midline is an important diagnostic feature in orthodontic treatment planning. Evaluation of dental midline position may be complicated because sometimes other midline facial structures are not well aligned. Correction of the dental midline deviation through orthodontic treatment often requires a complex biomechanics, difficult to achieve in the final stages of treatment, especially for an inexperienced orthodontist.

Although the dental midline deviation is commonly found in orthodontic practice, few studies have studied the prevalence of this anomaly, with an important role in facial aesthetics due to the dominant attribution of the anterior teeth while smiling and function [6-11].

Aim of our study was to establish the prevalence of dental midline deviation in mixed and permanent dentition in a group of orthodontic patients from the north-eastern region of Romania.

\section{Experimental part}

Materials and methods

We performed a retrospective study on a group of 384 orthodontic patients ( 164 boys and 220 girls), aged 6 to 23 (mean age $10.11 \pm 2.97$ years), from the north-eastern region of Romania. The patients came from different environmental areas (273 urban and 111 rural areas patients) and asked for orthodontic treatment in the Department of Orthodontics, Grigore T. Popa University of Medicine and Pharmacy lasi, during 2014-2016 period. All the patients included in the study were Caucasian and had no history of orthodontic treatment, no evidence of any syndrome, craniofacial malformation, or obvious facial asymmetry. From each patient who participated in the study informed consent was obtained. All data required for the study were collected from patients' orthodontic records. In order to be able to carry out the study the patients were classified according to gender $(42.70 \%$ boys and $57.30 \%$ girls), age intervals corresponding to the stages of dental permutation $(6-7$ years $=18.20 \%$ patients, $8-9$ years $=29.70 \%$ patients, $10-11$ years $=23.40 \%$ patients and $>12$ years $=28.60 \%$ patients), environmental areas (urban area $=71.10 \%$ patients and rural area $=28.90 \%$ patients), dentition types (mixed $=71.10 \%$ patients and permanent $=28.90 \%$ patients) and the diagnosis of malocclusion (Angle classification - class I $=69.80 \%$ patients, class II division $1=8.50 \%$ patients, class II division $2=6.80 \%$ patients and class $\mathrm{II}=4.90 \%$ patients). All analyses were carried out using the SPSS 20.0 for Windows (Armonk, NY, USA). The statistical evaluation of obtained data was done by descriptive statistics, Chi-square Pearson Tests, Fischer exact tests; any values less than $p<0.05$ were interpreted as statistically significant.

\section{Results and discussions}

In the studied group, the dental midline deviation was observed in $8.30 \%(n=32)$ patients in the mandible and in $12.50 \%(n=47)$ patients in the maxillary, resulting in $20.70 \%$ $(n=79)$ of the patients having the dental midline deviation (Fig. 1), interval of deviation being between $0-4 \mathrm{~mm}$ ( mean $0.40 \pm 0.86)$. 


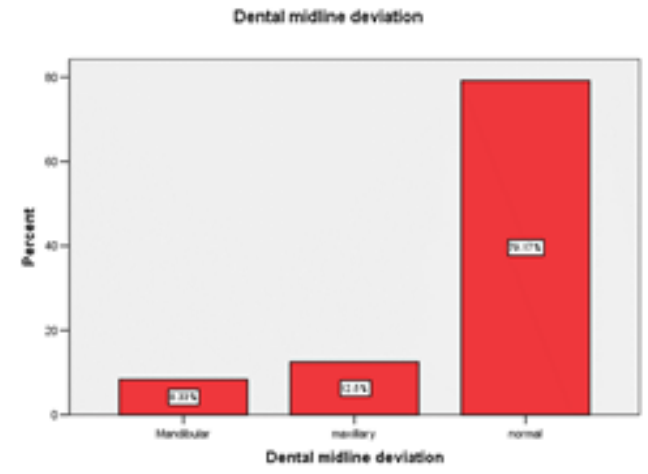

Fig. 1. The prevalence of dental midline deviation

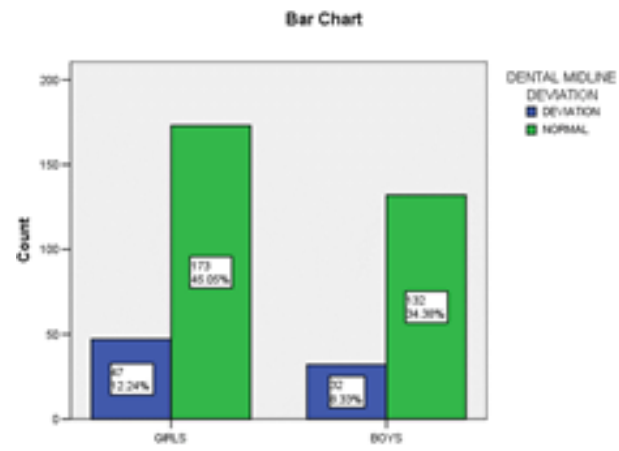

Fig. 2. The prevalence of dental midline deviation according to gender

\begin{tabular}{|c|c|c|c|c|c|c|c|c|}
\hline \multirow[t]{2}{*}{ Variables } & \multicolumn{2}{|c|}{$\begin{array}{c}\text { Dental } \\
\text { midline } \\
\text { deviation }\end{array}$} & \multicolumn{2}{|c|}{ Normal } & \multicolumn{2}{|c|}{ Total } & \multirow[t]{2}{*}{\begin{tabular}{|c|} 
Pearson \\
$\begin{array}{c}\text { Chi-Square } \\
\text { test }\end{array}$
\end{tabular}} & \multirow[t]{2}{*}{$\begin{array}{c}p \\
\text { value }\end{array}$} \\
\hline & $\mathrm{n}$ & $\%$ & $\mathrm{n}$ & $\%$ & $\mathrm{n}$ & $\%$ & & \\
\hline Gender & 79 & 20.57 & 305 & 79.43 & 384 & 100.00 & 0.197 & 0.657 \\
\hline male & 32 & 8.33 & 132 & 34.38 & 164 & 42.70 & & \\
\hline female & 47 & 12.23 & 173 & 45.05 & 220 & 57.30 & & \\
\hline Age stages & 79 & 20.57 & 305 & 79.43 & 384 & 100.00 & 9.122 & $0.028^{8}$ \\
\hline $6-7$ years & 8 & 2.08 & 62 & 16.15 & 70 & 18.23 & & \\
\hline $8-9$ years & 20 & 5.20 & 94 & 24.48 & 114 & 29.68 & & \\
\hline $10-11$ years & 19 & 4.95 & 71 & 18.49 & 90 & 23.44 & & \\
\hline$>12$ years & 32 & 8.34 & 78 & 20.31 & 110 & 28.65 & & \\
\hline Environment areas & 79 & 20.57 & 305 & 79.43 & 384 & 100.00 & 0.105 & 0.746 \\
\hline urban & 55 & 14.32 & 218 & 56.77 & 273 & 71.09 & & \\
\hline rural & 24 & 6.25 & 87 & 22.65 & 111 & 28.90 & & \\
\hline Dentition types & 79 & 20.57 & 305 & 79.43 & 384 & 100.00 & 11.475 & $0.001^{8}$ \\
\hline mixed & $\overline{44}$ & 11.45 & 229 & 59.64 & 273 & 71.09 & & \\
\hline permanent & 35 & 9.12 & 76 & 19.79 & 111 & 28.91 & & \\
\hline Angle malocclusions & 79 & 20.57 & 305 & 79.43 & 384 & 100.00 & 12.476 & $0.006^{8}$ \\
\hline Class I & 43 & 11.20 & 225 & 58.59 & 268 & 69.79 & & \\
\hline Class II division 1 & 24 & 6.25 & 47 & 12.24 & 71 & 18.49 & & \\
\hline Class II division 2 & 6 & 1.56 & 20 & 5.21 & 26 & 6.77 & & \\
\hline Class III & 6 & 1.56 & 13 & 3.39 & 19 & 4.95 & & \\
\hline
\end{tabular}

Table 1

THE CORRELATIONS BETWEEN DENTAL MIDLINE DEVIATION OF PATIENTSANDSTATISTICAL VARIABLES
In girls the deviation of dental midline was more frequent (12.24\%, $n=47)$ than in boys ( $8.33 \%, n=32$ boys) (fig. 2 and table 1).

The deviation of dental midline in the dental arch changed with age: at 6-7 years old were $2.08 \%(n=8)$ of the patients who had this anomaly, $5.20 \%(n=20)$ of the patients at $8-9$ years old, $4.95 \%(n=19)$ patients aged 10 11 years and $8.35 \%(n=32)$ patients over 12 years of age (fig. 3 and table 1).

The patients from urban area were more affected $(14.32 \%, n=55)$ compared to those in rural area $(6.25 \%$, $\mathrm{n}=24$ ) (fig. 4 and table 1).

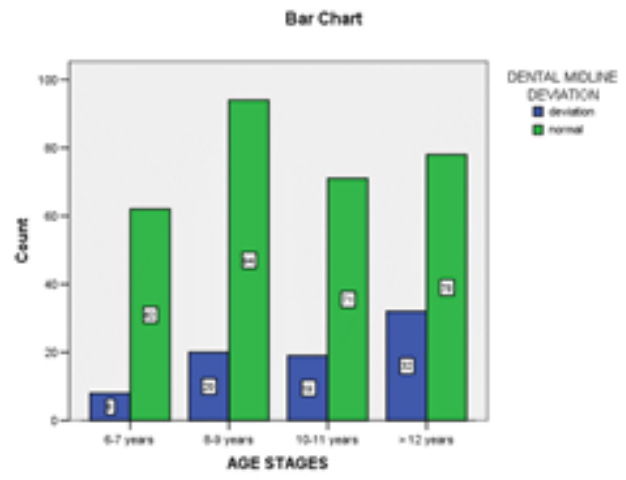

Fig. 3. The prevalence of dental midline deviation according to age stages

REV.CHIM.(Bucharest) $69 \bullet$ No. $12 \bullet 2018$

http://www.revistadechimie.ro
In the study group, 44 patients (11.46\%) with mixed dentition and 35 patients ( $9.11 \%$ ) with permanent dentition showed dental midline deviation (fig. 5 and table 1).

The dental midline deviation was observed in $11.20 \%$ $(n=45)$ of patients with Angle Class I and 6.25\% $(n=24)$ of patients with class II division 1 malocclusion (fig. 6 and table 1).

The Chi-square tests showed statistically significant high correlations between dental midline deviation and age stages $(p=0.028)$; Cramer coefficient (value of 0.153 ) indicates a weak relation, statistically significant between dental midline deviation and age stages of patients (table

Bar Chart
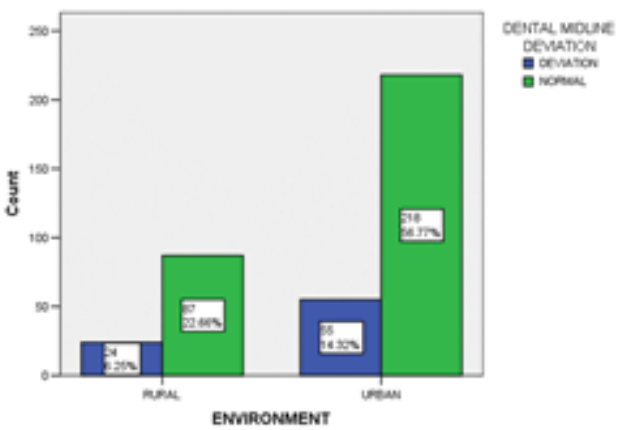

Fig. 4. The prevalence of dental midline deviation according to environment areas 


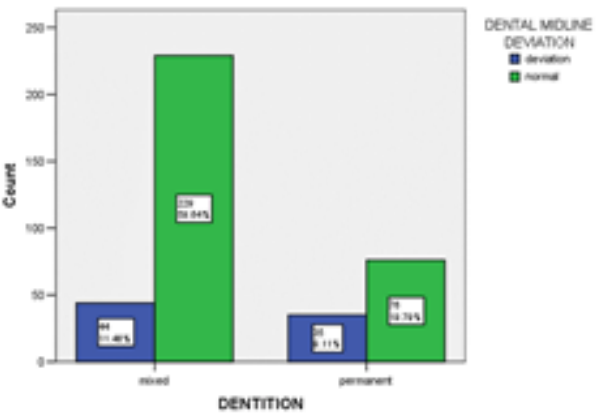

Fig. 5. The prevalence of dental midline deviation according to dentition types

1). We also found statistically significant high correlations $(p=0.001)$ between the deviation of the dental midline and the type of dentition (mixed or permanent); Cramer coefficient (value of 0.178 ) indicates a weak relation, statistically significant between dental midline deviation and type of dentition (table 1).

Statistically significant high correlations ( $p=0.001$ ) was found between the deviation of the dental midline and Angle classes of malocclusions ( $p=0.006$ ); Cramer coefficient (value of 0.180 ) indicates a weak relation (table 1 ). The Pearson test showed no statistically significant results between the deviation of the dental midline and gender and environment areas ( $p>0.05$ ) (table 1).

In this study we statistically evaluated a group of orthodontic patients in order determine the prevalence of dental midline deviation, according to gender, age stages, environment areas, types of dentition and Angle classes of malocclusions. Based on the data collected, 1/5 of the total patients presented the dental midline deviation, this being greater in the maxilla than the mandible. In girls the deviation of the dental midline was more frequent than in boys. The deviation of dental midline increased with age, the highest prevalence was in patients older than 12 years and in permanent dentition. In patients from urban area, dental midline deviation was more frequent than those from rural area. Deviation of dental midline was more frequent in patients with mixed dentition than those with permanent dentition and with Angle Class I and Class II division 1 malocclusions. Statistically significant high correlations were obtained between dental midline deviation and age stages, type of dentition and Angle classes of malocclusions. The explanation of these statistically significant correlations is related to the fact that after 12 years dental anomalies of the number, shape, dental volume, position, inclusion, dental crowding and the consequences of premature loss of temporary teeth causing the deviation of the dental midline are completely established.

Our study highlights the results of other studies that show that in patients presenting for orthodontic treatment, the maxillary and/or mandibular dental midlines often do not coincide with each other or with the facial soft-tissue midline. Bishara, Nanda, Lewis points out that the dental midline deviation midline deviation is clinical expression of skeletal asymmetries, or dental asymmetries (asymmetric crowding, spacing, tooth rotation, or tooth size discrepancies) $[5,12,13]$.

Face symmetry and median line coordination are essential criteria for achieving harmony and facial balance. Miller et al. indicate that the maxillary medial line is located exactly in the middle of about $70 \%$ of the person, but the maxillary and mandibular midlines coincide only to $1 / 4$ of the population [14]. Dental midline discrepancy is aesthetically evident and is perceived by the patient and

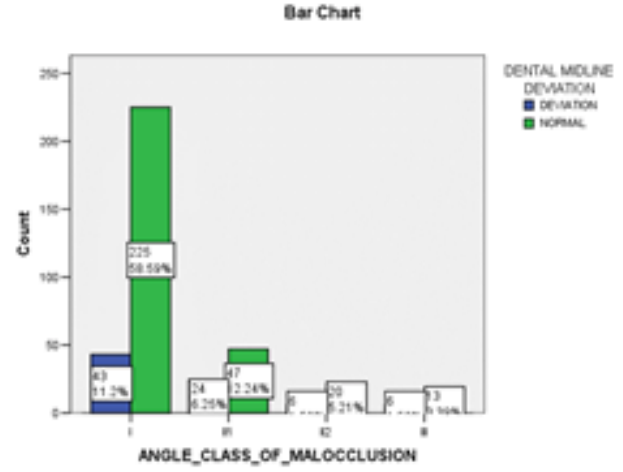

Fig. 6. The prevalence of dental midline deviation according to Angle classes of malocclusion

should therefore be treated [15]. In practice, the consequence of an orthodontic superficial diagnosis causes minor asymmetries to go unnoticed; these can occur in the finishing stages when they are difficult to treat $[16,17,19-24]$. In his work Burstone shows that there are clinical situations when approaching dental midline deviation by using inadequate techniques or devices often results in unwanted effects that may be more serious than asymmetry itself [18].

Existing studies have shown importance in facial aesthetics and prosthetic restoration of the frontal area of dental midline deviation. The present study is of interest because it analyses the prevalence the dental midline deviation in a group of orthodontic patients and points out the changes according to demographic criteria and malocclusion classes.

\section{Conclusions}

Dental midline deviation was more common in patients over 12 years of age and in Angle Class I and II division 1 malocclusions.

Dental midline deviation is correlated statistically significantly with age stages, type of dentition and Angle classes of malocclusion.

Dental midline deviation warrant special consideration in orthodontic diagnosis and treatment planning process.

\section{References}

1.BIDRA AS, URIBE F, TAYLOR TD, AGAR JR, RUNGRUANGANUNT $P$, NEACE WP. The relationship of facial anatomic landmarks with midlines of the face and mouth. J Prosth Dent 2009; 102(2):94-103.

2.PENG L, COCKE MS. Fifteen year reproducibility of natural head posture: A Longitudinal study. Am J Orthod Dentofacial Orthop 1999; 116:82-85.

3.ESKELSEN E, FERNANDES CB, PELOGIA F, CUNHA LG, PALLOS D, NEISSER MP, LIPORONI PCS. Concurrence between the maxillary midline and the bisector to the interpupillary line. J Esthet Restor Dent 2009; 21(1):37-42.

4.FARHAN KM, KHEZRAN Q, SAJID N. Coincidence of facial midline with dental midline. Pak Oral Dental J 2014; 34(2):355-357.

5.BISHARA SE, BURKEY PS, KHAROUF JG. Dental and facial asymmetries: A review. Angle Orthod 1994; 64:89-97.

6.J ERROLD L, LOWENSTEIN LJ . The midline: diagnosis and treatment. Am J Orthod Dentofacial Orthop 1990; 97:453-462.

7.BEYER JW, LINDAUER SJ. Evaluation of dental midline position. Semin Orthod 1998; 4:146-152.

8.J OHNSTON CD, BURDEN DJ, STEVENSON MR. The influence of dental to facial midline discrepancies on dental attractiveness ratings. Eur J Orthod 1999; 21:517-522.

9.MAVANI S, RAMESH TR, PATEL N, PATEL V. Evaluation of coincidence of facial midline to dental midline and maxillary midline to mandibular midline in undergraduate students. Int J Adv Res 2017; 5(2); 23642369. 
10.KHAN MF, QAMAR K, NAEEM S. Coincidence of facial midline with dental midline. Pak Oral Dental J 2014; 34(2):355-357.

11.TJAN AH, MILLER GD. Some esthetic factors in a smile. J Prosth Dent 1984; 51:24-28.

12. NANDA R, MARGOLIS MJ. Treatment strategies tor midline discrepancies. Semin Orthod 1996; 2:84-89.

13.LEWIS PD. The deviated midline. Am J Orthod 1976; 70:601-616.

14.MILLER EL, BODDEN J R, JAMISON HC. A study of the relationship of the dental midline to the facial median line. J Prosthet Dent, St. Louis 1979; 41(6):657-660.

15.SILVA BP, JIMENEZ-CASTELLANOS E, Martinez-de-Fuentes $R$, Fernandez AA, Chu S. Perception of maxillary dental midline shift in asymmetric faces. Int J Esthet Dent 2015; Winter;10(4):588-596.

16.FENG X, YANG Z, DAI J, LI R. Miniscrew anchorage for the correction of midline discrepancies. J Clin Orthod 2014; 48:169-179.

17. KAI R, UMEKI D, SEKIYA T, NAKAMURA Y. Defining the location of the dental midline is critical for oral esthetics in camouflage orthodontic treatment of facial asymmetry. Am J Orthod Dentofacial Orthop 2016; 150(6):1028-1038.

18.BURSTONE CJ. Diagnosis and treatment planning of patients with asymmetries. Semin Orthod 1998; 4:153-164.
19.CARAUSU,E.M., DASCALU,C.G., ZEGAN,G, et al., The general and oral heath status in older adults from rural environment of lasi, Country, Romania, Revista de Cercetare si Interventie sociala,Vol.59,2017, pg.187-208

20.MATEI,M.N., EARAR, K., TRINCA,L.C., Degradation characteristics of poly-tetrafluorethylene coatings on stainless steel orthodontic wires immersed in tuna fish derived products, Rev. Chim. (Bucharest), 67, no. 4, 2016, p.800-807

21.MARECI, D., EARAR, K., ZETU, I., et al., Comparative electrochemical behaviour of uncoated and coated $\mathrm{Ni}$-Ti for dental orthodontic wires, Mat. Plast., 52, no. 2, 2015, p.150-153

22.ANTOHE, M.E., FORNA AGOP, D., DASCALU, C.G., Implications of digital image processing in the paraclinical assessment of the partially edentated patient, Rev. Chim. (Bucharest), 69, no. 2, 2018 p.521-524 23.POPESCU, E, AGOP FORNA, D., EARAR, K., FORNA, N.C., Bone substitutes used in guided bone regeneration technique review, Mat. Plast., 54, no.2, 2017, p. 390-392

24.CHECHERITA, L., BELDIMAN, M.A., STAMATIN ,O., et al. Aspects on structure of materials used for different types of occlusal splints. 64(8), 2013,pg.864-867

Manuscript received: 15.08 .2018 